\title{
HISTORY OF DEVELOPMENT AND TERRESTRIALIZATION OF LAKE STAROWLANY IN THE EEMIAN INTERGLACIAL BASED ON CLADOCERA ANALYSIS (SOKÓLKA HILLS, NE POLAND)
}

\author{
Monika Niska, Anna Kołodziej \\ Pomeranian University in Stupsk, Institute of Geographical Sciences and Regional Studies, Partyzantów 27, \\ 76-200 Stupsk, Poland; e-mail: monikaniska@wp.pl
}

\begin{abstract}
This paper presents development of the paleolake Starowlany existing in the Eemian Interglacial (MIS 5e) in northeastern Poland. The lake history is based on Cladocera analysis. The paleolake Starowlany is located in the central part of the Sokółka Hills, approximately 9 km north of the town of Sokółka in the North Podlasie Lowland. The sediments studied filled a southern part of a tunnel valley formed during the Warta Glaciation. The coring was carried out with a geological drilling and constituted a part of the framework aimed at preparing the Sokółka sheet for the Detailed Geological Map of Poland in scale 1:50 000. The core was $7 \mathrm{~m}$ long. Peaty silt, peats and organic silt were present at the depth of 4.0-6.6 m, under deluvial sands, tills and silt. Organic series was overlain by a clayey silt with no glacial cover. Cladocera analysis was conducted with 20 samples from a depth interval 6.6-4.1 m. Remains of 17 species of Cladocera were found, representing the families: Chydoridae, Sididae and Bosminidae. A vast majority of them were the littoral species. In the paleolake Starowlany four development zones were distinguished that reflected changes as regards temperature, trophic levels and changes of water level in the lake. The paleolake existed from the early until the middle Eemian. The highest water level and the most favorable conditions for zooplankton development occurred in zones SCZ I and II. The highest trophic level took place in SCZ III (middle Eemian). In the late Eemian the water level dropped and the paleolake was transformed into a wetland. At certain points, the higher water level enabled existence of a few Cladocera species. The reasons for disappearance of the paleolake Starowlany included a local decrease in groundwater levels as well as morphometric and geological characteristics of the lake.
\end{abstract}

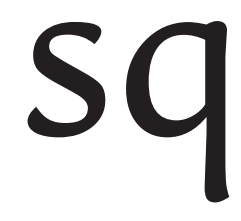

Key words: Cladocera analysis, Eemian Interglacial, palaeolake development, NE Poland.

Manuscript received 7 November 2014, accepted 27 May 2015

\section{INTRODUCTION}

Functioning of lakes is a short-term phenomenon in a geological time scale. Emerging of lakes in a temperate zone was connected in the Pleistocene with climate change, withdrawal of glaciers and arising of numerous land depressions where water could collect. From the beginning of their existence, lakes gradually transformed: they were gradually filled with sediments and overgrown with plants; trophic conditions, water chemistry and organisms inhabiting the lakes were also a subject to change. These processes could result in a complete disappearance of a lake (Zhang et al., 2012). In natural circumstances, such processes take place very slowly, but human activity makes them hundreds or even thousands of times quicker (Kajak, 2001).

Lakes constitute an excellent archive, accumulating remains of a changing environment and recording successive stages of the natural history. Thanks to paleolimnological research, it is possible to trace back the environmental changes that accompanied an evolution of lakes. Biological remains are preserved in lake sediments and can be used as a "proxy" to determine environmental conditions.

Remains of Cladocerans are an important paleolimnological proxy. Cladocera (Crustacea) are small aquatic organisms belonging to zooplankton and zoobenthos (Rybak and Błędzki, 2010). They are an important part of a lake biocenosis as a whole. Their diversity and sensitivity to environmental changes, as well as a contemporary knowledge on ecological requirements of individual species, make Cladocera a very good indicator of changes that have occurred in a lake environment and its surroundings (Szeroczyńska, 1985). A number of research centers in Poland and all over the world have examined remains of fossil Cladocera for over 90 years.

Sediments from before the Holocene have been studied since the sixties of the twentieth century. Frey (1962) was the pioneer in research of the Eemian Cladocera in Danish lakes. Over the years, fossil Cladocera were analyzed in other research sites of the Eemian Interglacial, namely in Japan (Tsukada, 1972; Kadota, 1975) and Canada (Hann and Kar- 


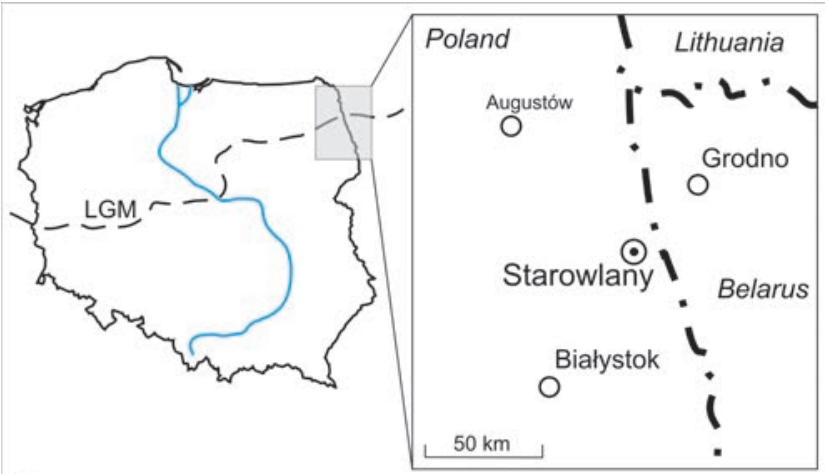

$\odot$ Cladocera analysis

LGM - maximum ranges of the Vistulian Glacial

Fig. 1. Location of the Eemian section Starowlany in northeastern Poland.

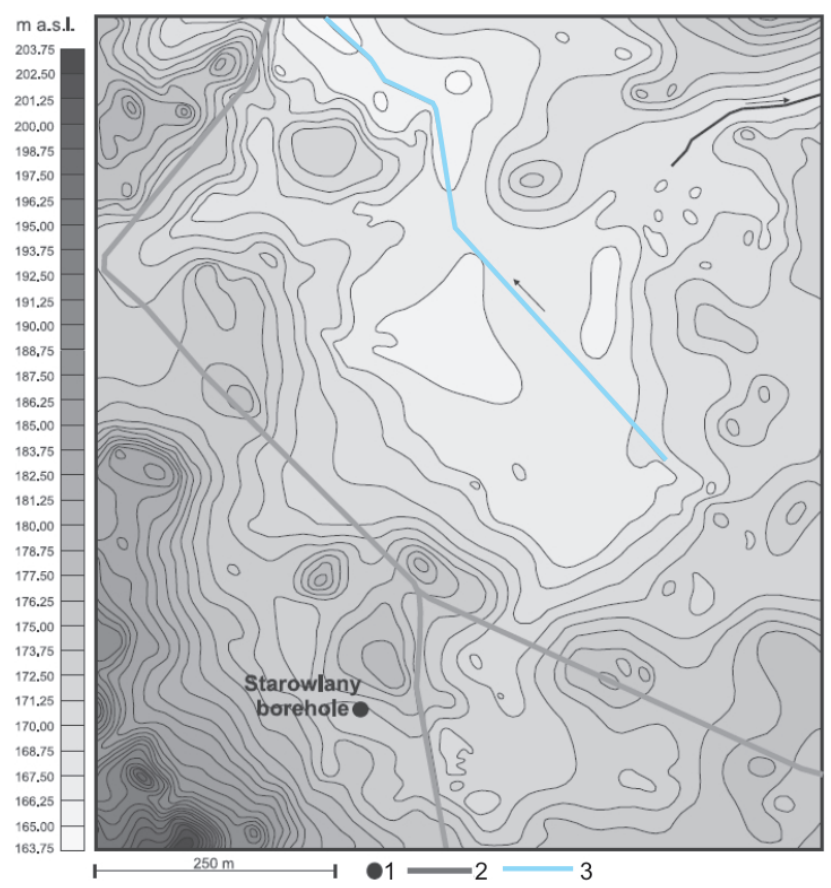

Fig. 2. Location of the Starowlany site. 1 - studied profile, 2 roads, 3 - stream (Kupryjanowicz, 2008).

row, 1984, 1993). In Poland, the first studied sediments of the Eemian were those of the Konin profile (Tobolski, 1991).

The Eemian Interglacial was the last warm period before the Vistulian Glaciation Weichselian). As reported by Hearty et al. (2007), it began 130000 years ago and lasted until 119000 years ago. It is believed to be related with MIS 5e, the period of global sea-level rise determined based on analysis of oxygen isotopes from deep-sea sediments (Hearty et al., 2007).

In Poland, a development of lake environments was subject to ice sheet retreat of the Warta Glaciation. In the Podlasie region, there are traces of a lake district with numerous water bodies in many land depressions (Boratyn, 2006).

In the contemporary interglacial (Holocene), an increasing human inmpact upon the environment has caused a disruption of natural ecosystem processes. The analysis of the environmental variability during the present interglacial period unaffected by human activity enables learning about natural paleoenvironmental changes modeled by global and regional climatic factors (Cheddadi, et al., 1998).

The aim of the present study is a reconstruction of evolution of the Lake Starowlany, as well as establishing reasons of its terrestrialization in the light of climatic and environmental changes during the Eemian Interglacial, based on the Cladocera analysis.

The results obtained enabled to determine changes of water level, temperature and lake fertility, which had been taking place under the influence of natural processes.

\section{MATERIALS AND METHODS}

\section{Study site}

Sokółka Hills are located within North Podlasie Lowland in the north-eastern part of Poland (Fig. 1). In the central part of Sokółka Hills, approximately $9 \mathrm{~km}$ north of the town Sokółka, the Lake Starowlany site is located $\left(53^{\circ} 30^{\prime} \mathrm{N}\right.$, $23^{\circ} 23^{\prime} \mathrm{E} ; 172 \mathrm{~m}$ a.s.1.). The palaeolake in which the study was carried out is located about $50 \mathrm{~m}$ to the west of the Starowlany-Popławce road (Fig. 2). The sediments studied fill a southern part of the glacial tunnel that was formed during the Warta Glaciation. The paleolake basin extends over an area of $700 \mathrm{~m} \times 400 \mathrm{~m}$ (Kupryjanowicz, 2008).

\section{Lithology}

The coring was carried out with a geological drill and constituted a part of the framework during elaboration of the Sokółka sheet for the Detailed Geological Map of Poland in scale 1:50 000 (Boratyn, 2003, 2006). The sequence obtained was $7 \mathrm{~m}$ long (Tab. 1). Peaty silts, peats and organic silts were present at the depth of 4.0-6.6 m, under deluvial sands, tills and silts. Organic series were covered by clayey silts. A characteristic feature of such setting of the Eemian deposits (as well as in other sites in the area) is a lack of glacial cover. It supports a view of a lack of covering of the Białystok Upland and Sokółka Hills by the last Scandinavian ice sheet (Krzywicki, 2006). The Cladocera samples were collected at depth of $6.70-4.10 \mathrm{~m}$. The material was dried and strongly compacted, which made it impossible to collect volume samples.

\section{Methods}

The Cladocera analysis was performed using 20 samples collected in irregular intervals $(10-20 \mathrm{~cm})$ from the depth 4.0-6.6 $\mathrm{m}$. The samples of $1 \mathrm{~g}$, were prepared according to a slightly modified standard procedure (Frey, 1986, Korhola and Rautio, 2001). After removal of carbonates using $\mathrm{HCl}$, each sample was boiled in $10 \% \mathrm{KOH}$ for 20 minutes. After washing the residue with distilled water, it was sieved through a $40-\mu \mathrm{m}$ mesh sieve. A fine material was transferred into a polycarbon test tube. Prior to counting, the remains were colored with safranine $\mathrm{T}$. The analysis with microscope was performed using a Nikon model ECLIPSE Ci-L. The preparations were analyzed using magnifications $\times 10, \times 40$ and $\times 60$ (Fig. 3). Nikon microscope cameras were used to take photographs. A minimum of 200 remains of Cladocera 
(3-8 slides) were examined in each sample. Firstly, all remains from each slide were counted (headshield, shell, postabdomen, postabdominal claws, and antennules) and then converted to a single Cladocera specimen. The identification and ecological interpretation of the Cladocera remains were conducted on the basis of studies of Duigan (1992), Frey (1958, 1962), Goulden (1964), Hofmann (1986, 2000), Korhola (1990), Flössner (2000) Szeroczyńska (1985, 1998b), and Szeroczyńska and Sarmaja-Korjonen (2007).

Results of Cladocera analyses are presented as a concentration diagram (Fig. 4), a percentage diagram (Fig. 5), a total number of Cladocera individuals and a number of species including their biodiversity (Fig. 6). The numerical analysis was determined by constrained single link cluster analysis (ConSlink - square-root transformation of \% data) using the POLPAL computer program (Nalepka and Walanus, 2003).

The Cladocera species were divided into three habitat preference groups: bottom-dweller species, species associated with vegetation, species restricted to vegetation (Korhola, 1990; Flössner, 1964; Whiteside, 1970; Hofmann, 1987; Whiteside and Swindoll 1988). They were also divided into planktonic (offshore) and littoral (meiobenthic) groups (Mueller, 1964).

Pollen analysis was conducted by Daniluk (2005) and Kupryjanowicz (2008). Basing on this analysis, seven local pollen assemblages zones (L PAZ) were determined for the Starowlany section, correlated with regional pollen assemblages zone (R PAZ) (Mamakowa, 1989) (Fig. 6). The stratigraphy of the Starowlany section used in the Cladocera analysis was based on results of a palynological analysis.

\section{RESULTS}

In the sediments of the Starowlany profile, remains of 17 species of Cladocera were found. They belonged to three families: Chydoridae, Sididae and Bosminidae. Among the species, a vast majority were the ones from a littoral zone (16) and Eubosmina coregoni only could be counted as a pelagic species.

The Eemian remains in the Starowlany section were poorly preserved, largely damaged, torn, with a poorly marked characteristic structure of dorsal carapaces and head shield. The impact on the condition of the remains had their age and a significant dry sludge during storage (Fig. 3). Remains of Cladocera determined in sediments are similar to the contemporary species in Poland (Szeroczyńska, 1998a).

On the basis of changes in frequency and number of species and specimens of Cladocera as well as indicator species, four main zones of the Cladocera succession were determined.

Zone I (SCZ I) (6.70-6.30 m): seven Cladocera species were determined. A total frequency amounted to 200-500 individuals per $1 \mathrm{~g}$ of sediment (Fig. 6) and it was characterized by a downward trend. At first, Chydorus sphaericus dominated, with $90 \%$ contribution (Fig. 5). At the beginning of first zone, remains of the Acroperus harpae, small Alona and Alonella nana were also preserved (Fig. 4). However, their contribution was scarce. Next, the frequency of the following species increased: Alona affinis (up to 50\%), Eurycercus lamellatus (up to $20 \%$ ) and Sida crystallina (up to 15\%) ex-
Table 1

Lithology of the Starowlany section

(Boratyn, 2006; Kupryjanowicz, 2008)

\begin{tabular}{|l|l|}
\hline Depth $(\mathrm{m})$ & Sediment description \\
\hline $0.00-0.80$ & fine sand, rust \\
\hline $0.80-2.80$ & $\begin{array}{l}\text { till-sandy sediment with gravel, deluvial, horizontally } \\
\text { stratified, brown-olive }\end{array}$ \\
\hline $2.80-3.60$ & fine and medium sand, dark grey \\
\hline $3.60-4.00$ & clayey silt, dark grey \\
\hline $4.00-4.50$ & $\begin{array}{l}\text { clayey silt with high content of organic matter, dark } \\
\text { brown }\end{array}$ \\
\hline $4.50-4.85$ & clayey silt, dark brown \\
\hline $4.85-5.30$ & peaty silt, very dark brown \\
\hline $5.30-5.50$ & peat, weakly decomposed, brown \\
\hline $4.85-5.30$ & peaty silt, very dark brown \\
\hline $5.30-5.50$ & peat, weakly decomposed, brown \\
\hline $5.50-6.10$ & peat, highly decomposed, dark brown \\
\hline $6.10-6.45$ & peaty silt, very dark grey \\
\hline $6.45-6.60$ & organic silt, clayey, plastic, grey-black \\
\hline $6.60-7.00$ & clayey silt, dark grey \\
\hline $7.00-8.50$ & clayey silt, grey \\
\hline
\end{tabular}

isting among the aquatic vegetation of clear and calm waters (Flössner, 1972).

Zone II (SCZ II) (6.30-5.95 m) - a number of determined species increased up to 10. A general frequency of individuals decreased in comparison with the zone I and was equal from 200 to 300 individuals per $1 \mathrm{~g}$ of sediment (Fig. 6). At the beginning of this zone, remains of the following species were determined: Chydorus sphaericus (45\%), Eurycercus lamellatus (25\%) and a few remains of transiently occurring Eubosmina coregoni associated with a pelagic zone. As well as this, presence of Acroperus harpae, Alona affinis, Camptocercus rectirostris and Sida crystallina was noted. In the final subzone, remains of Alonella exigua, small Alona and Leydigia acanthocercoides occurred (Fig. 4).

Zone III (SCZ III) (5.95-5.00 m): the largest frequency of remains and the largest number of species was noted. Due to the differences in frequency of Cladocera individuals, three subzones were distinguished:

Subzone a (5.95-5.55 m) - the largest total frequency of individuals was noted, with 1100 indviduals per $1 \mathrm{~g}$ of sediment (Fig. 6). A number of preserved species decreased to seven. The largest frequency was noted of Chydorus sphaericus (approx. 40\%), Acroperus harpae (approx. 50\%), Alona affinis (approx. 10-30\%) and small Alona (approx. 15\%) (Fig. 5). At the beginning of the subzone a, Acroperus elongatus occurred with a species dwelling in the bottom and in a final part of the subzone a, the species Alonella excisa and Pleuroxus trigonellus were noted, however their contribution was scarce (Fig. 4).

Subzone b (5.55-5.40 m) - a significant decrease in a number of preserved species was noted (to 5 ) and a decrease of total frequency of Cladocera individuals to $300 / 1 \mathrm{~g}$ of sediments (Fig. 6). A frequency of individuals of all species decreased. The dominant species were Acroperus harpae (up to 45\%) and Alona affinis (up to 30\%). Alonella excisa, Eurycercus lamellatus and small Alona were those of smaller contri- 


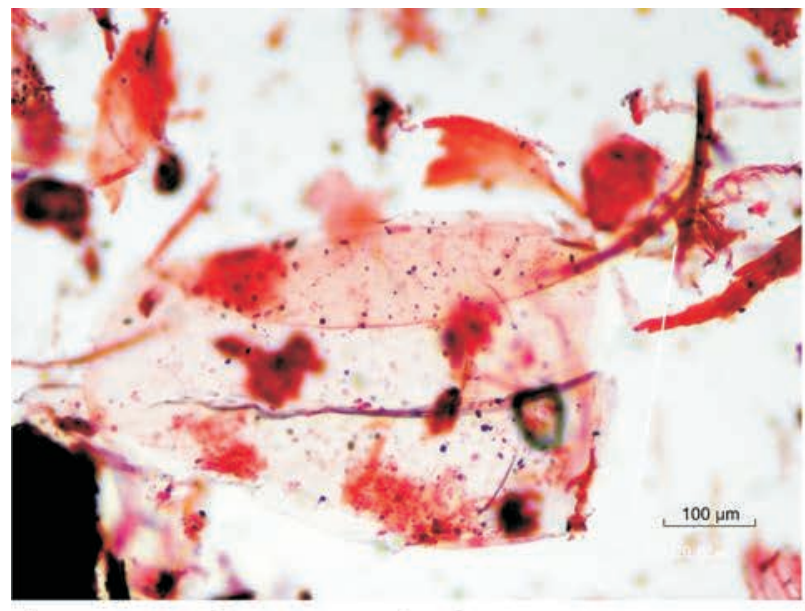

Acroperus harpae - shell

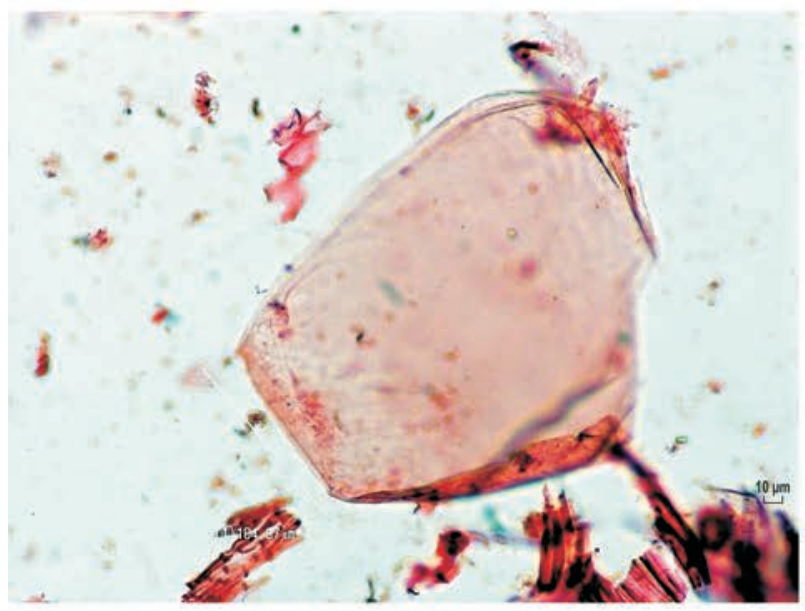

Alonella excisa - shell

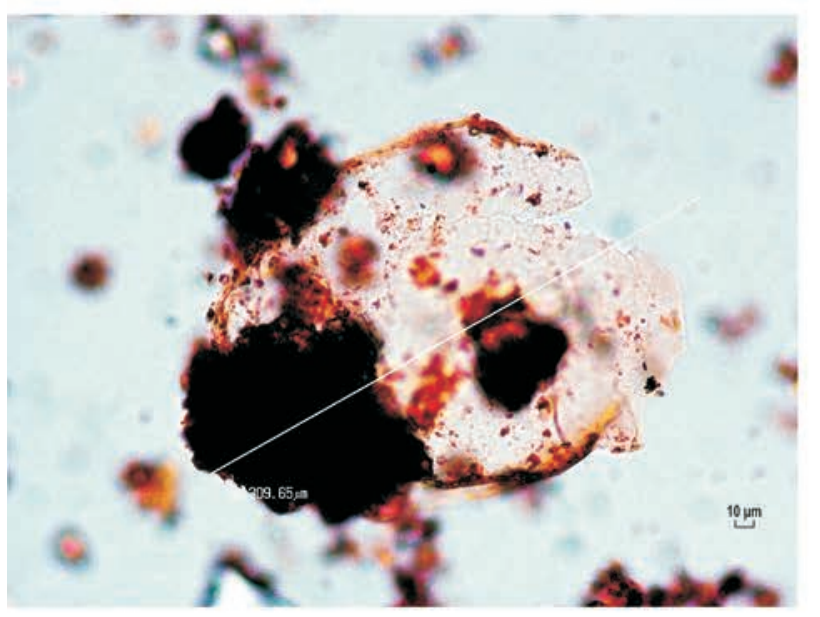

Chydorus sphaericus - head shield

Fig. 3. Subfossils Cladocera remains from the Starowlany section

bution (Fig. 4). The species of Pleuroxus trigonellus and Chydorus sphaericus withdrew.

Subzone c (5.40-5.00 m) - a renewed increase in frequency of individuals was noted, as well as return of species

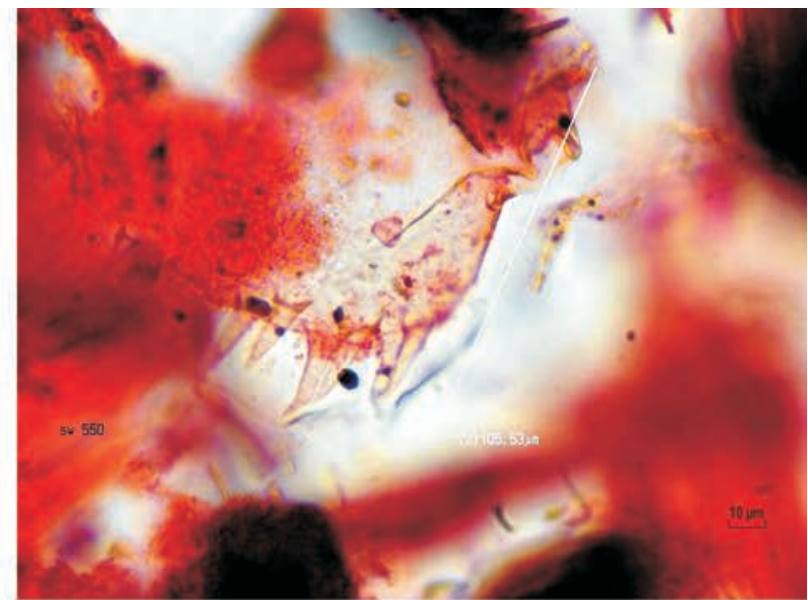

Alona affinis - postabdomen

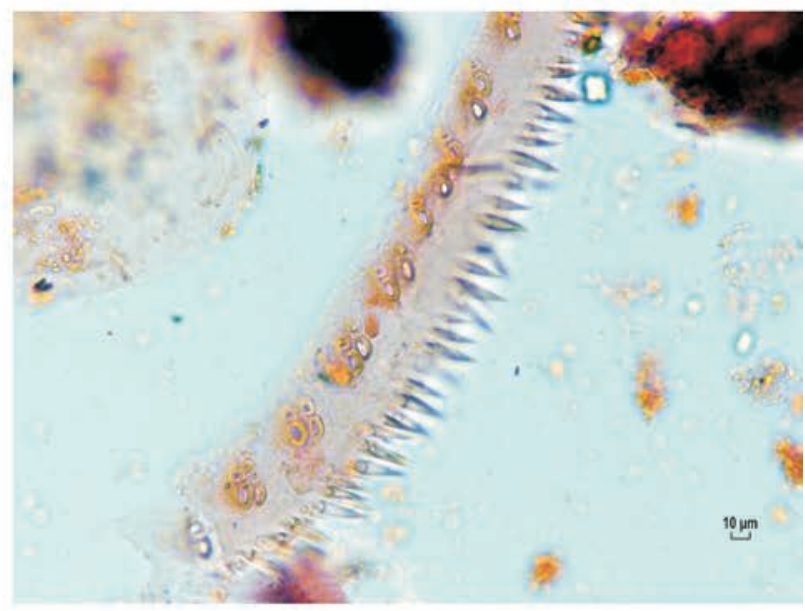

Leydigia acanthocercoides - postabdomen

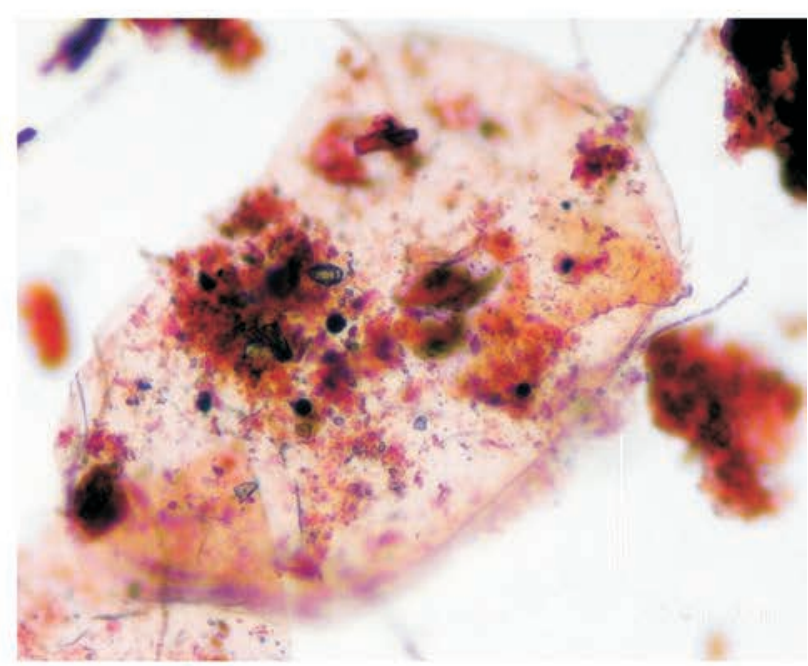

Pleuroxus trigonellus - shell

of the subzone a and emergence of new Cladocera species. The subzone $\mathrm{c}$ indicates a maximum number of species in the section, bearing evidence of high biodiversity with 14 Cladocera species. A general frequency increased up to 1100 indi- 


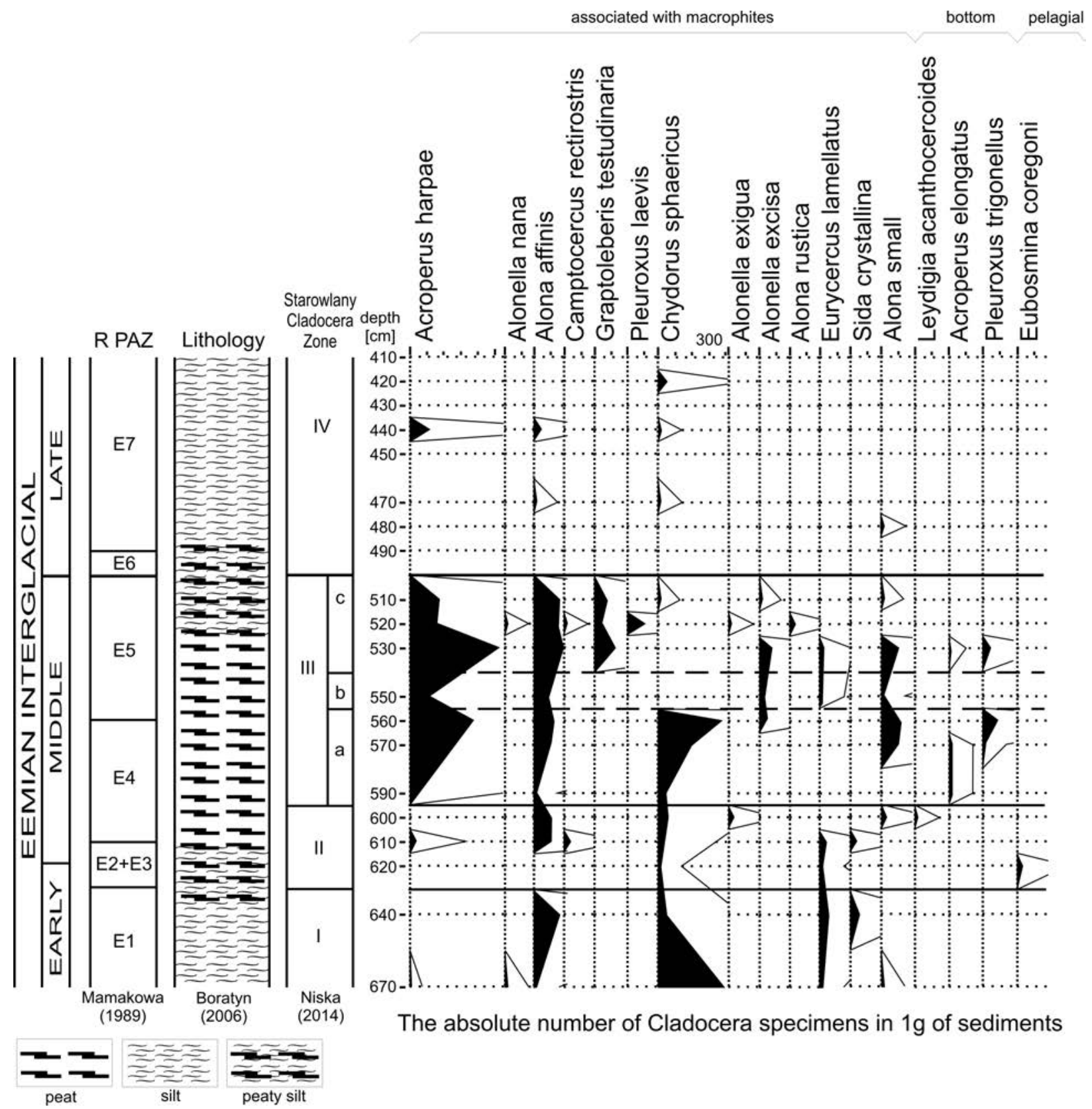

Fig. 4. Diagram of the absolute number of Cladocera individuals in sediments of the Starowlany section.

viduals per $1 \mathrm{~g}$ of sediment (Fig. 6). The dominant species in the subzone were: Acroperus harpae (approx. $520 \mathrm{ind} / 1 \mathrm{~g}$ ), Alona affinis (approx. $170 \mathrm{ind} / \mathrm{g}$ ) and Graptoleberis testudinaria (approx. $120 \mathrm{ind} / \mathrm{g}$ ), achieving maximum frequency. At the beginning of the subzone the following species were preserved in the sediments: Acroperus elongatus, Pleuroxus trigonellus, Alonella excisa, Eurycercus lamellatus and small Alona. After their withdrawal, Pleuroxus laevis, Alonella nana, Camptocercus rectirostris, Alona rustica and Alona exigua appeared. The final period of the subzone was characterized by a return of small Alona, Alonella excisa and Chydorus sphaericus. The subzone c terminated with a withdrawal of all species (Fig. 4).

Zone IV (SCZ IV) (5.00-4.10 m) - a number of preserved species decreased to four. A total frequency was very low, up to 115 individuals per $1 \mathrm{~g}$ of sediment (Fig. 6). In this zone, remains of the species Alona affinis, small Alona, Chydorus sphaericus and Acroperus harpae were preserved. The zone is characterized by a discontinuous record of Cladocera. At the depth of 500-485 cm, 435-425 cm and $460-445 \mathrm{~cm}$ no remains of Cladocera were preserved.

\section{DISCUSSION}

\section{Reconstruction of development of the palaeolake Starowlany}

Ecological preferences of Cladocera were used to reconstruct changes in water level, temperature and trophic status of the lake water. Faunal results were compared with palynological data of Kupryjanowicz (2008) and Daniluk (2005). 


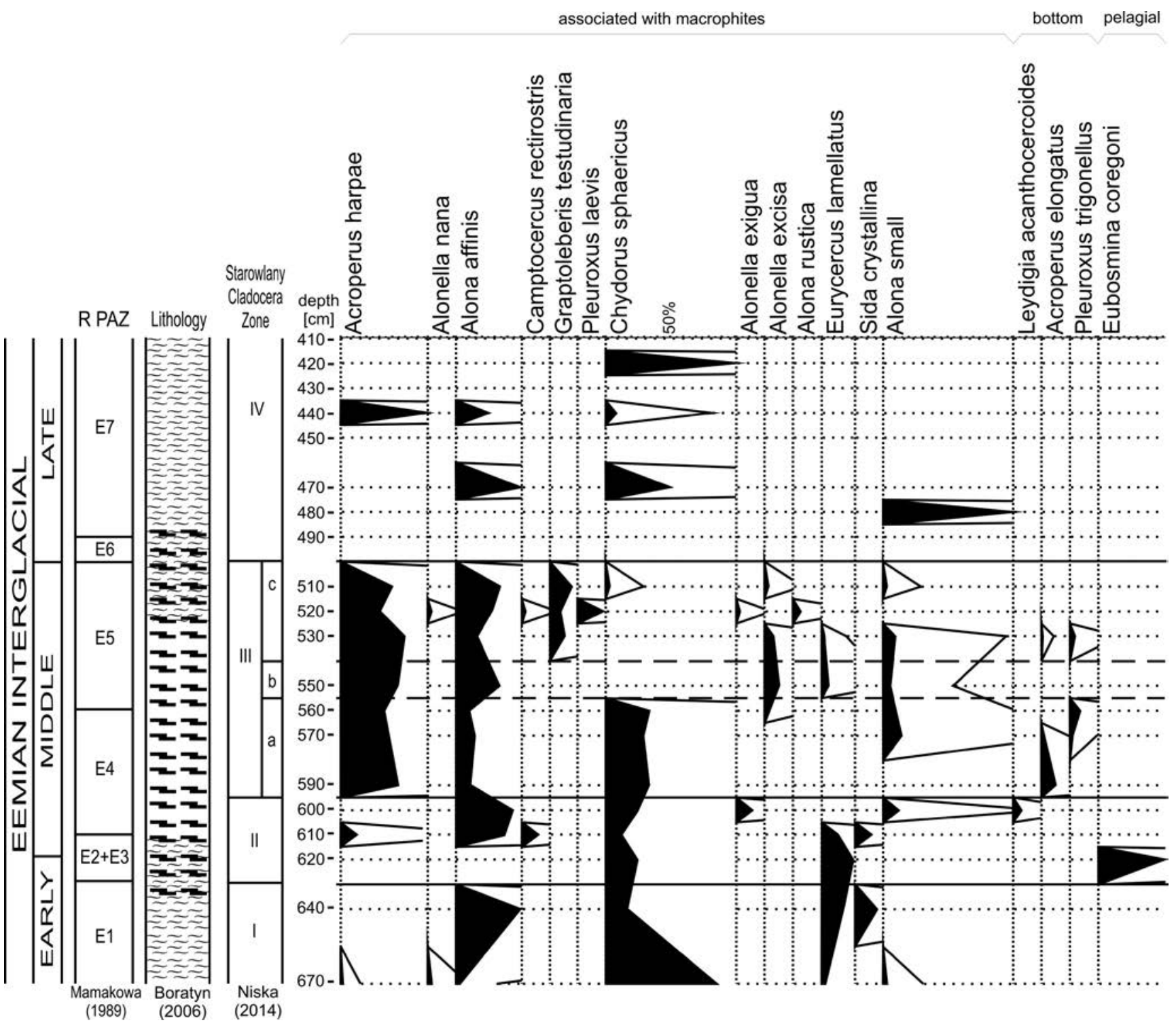

Fig. 5. Percentage Cladocera diagram of the Starowlany section

\section{Early Eemian (St-1, St-2 L PAZ, Kupryjanowicz 2008)}

Basing on palynological studies, the age of sediments in the lowest, bottom part of the Starowlany profile, was established as early Eemian (L PAZ St-1, R PAZ - E1; Kupryjanowicz 2008). The sediments from this period contain remains of pioneer species of Cladocera (SCZ I), belonging to the so-called "arctic species": Chydorus sphaericus, Alona affinis, as well as three other species enduring low temperatures: Acroperus harpae, Alonella nana and Eurycercus lamellatus (Hofmann, 2000). It indicates low water temperature of the lake Starowlany in the earliest studied period. Afterwards, a water temperature increased, enabling settlement of the lake by species more demandant in terms of temperature: Sida crystallina (Rybak and Błędzki, 2010). High frequency of Chydorus sphaericus may indicate a higher trophic level of the lake water. Deficiency of bottom-dwelling species can be associated with a higher water level of the lake. Palynological studies of water and rushes in the section indicate a depth of the then lake (maximum $6 \mathrm{~m}$ ). Pollen analysis of forest communities indicates a boreal nature of the climate in this phase (Daniluk, 2005).

The next phase of lake development (SCZ II, L PAZ St-2, R PAZ E2/E3) falls on interglacial transition from its early to middle phase, but a transition point is difficult to determine. Initially, in this phase there was a change in species composition. Some species withdrew and were replaced by the only species found that represented deep-water dwellers: Eubosmina coregoni (Korhola, 1990). This change of species composition could indicate deepening of the lake, which appears consistent with a general trend of development of reservoirs in the northern Podlasie. The trend was that lakes in the northern Podlasie gradually deepened, because of continuous supply with water from melting glaciers, higher rainfall and possibly, a higher groundwater level (Kupryjano- 


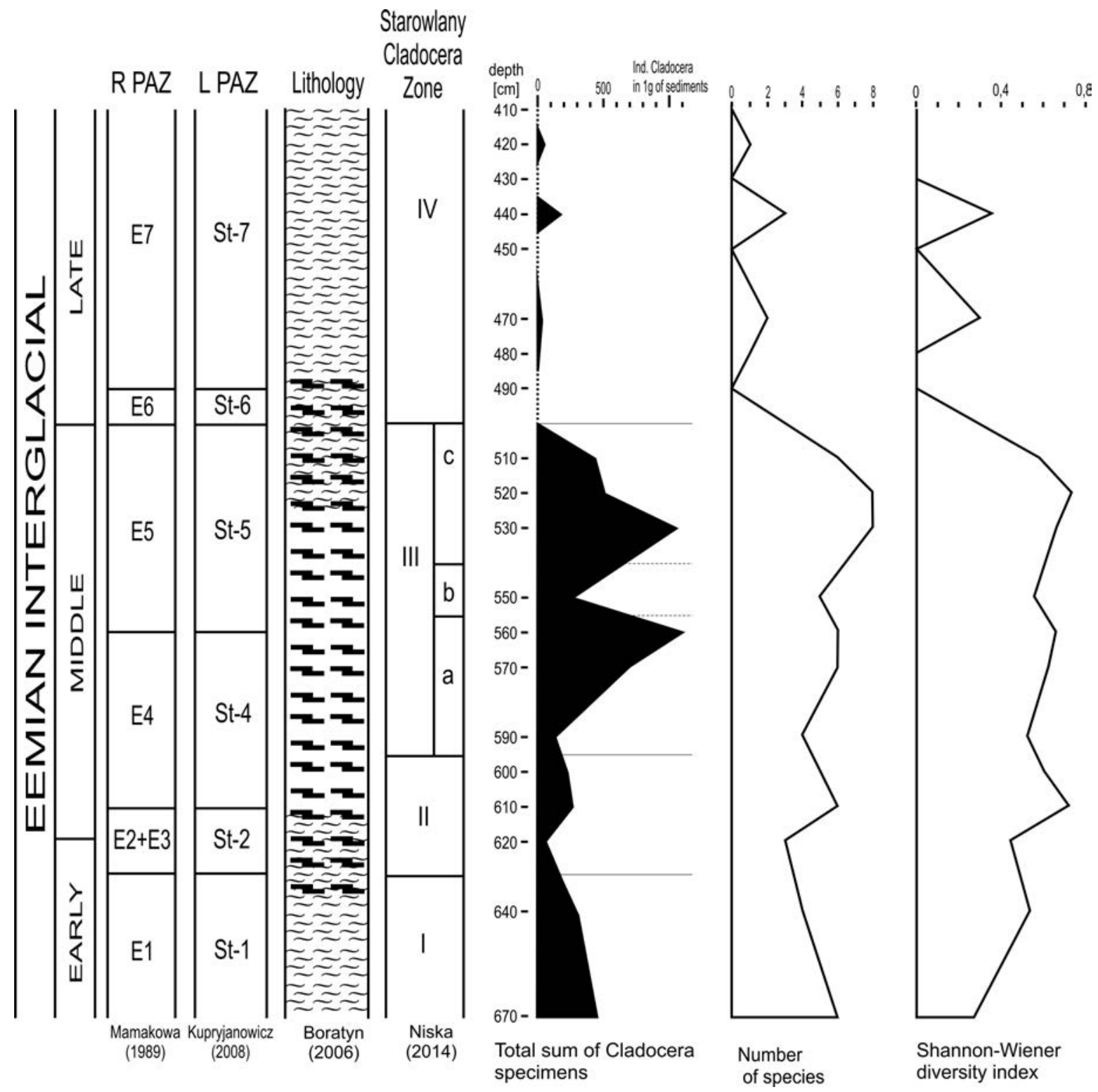

Fig. 6. Diagram of the total number of Cladocera specimens, number of species and Shannon-Wiener biodiversity index in the Starowlany section

wicz, 2008). Nevertheless, in sediments at the depth of $6.15 \mathrm{~m}$ there was a mixing of material. There was a layer of peaty silt and sand inserts and probably no sediments from E3 (Kupryjanowicz, 2008). Such situation does not allow to state a clear conclusion on a depth of the lake.

\section{Middle Eemian (SCZ II, III; L PAZ St-3, St-4, St-5, R PAZ E3-E5, Kupryjanowicz 2008)}

A beginning of the middle Eemian (L PAZ St-4) was associated with definite improvement in living conditions of a zooplankton in the reservoir (SCZ II - the second half) as evidenced by increased species diversity. The Camptocercus rectirostris species with higher thermal requirements appeared (Hofmann, 2000). Its co-existence with the species of Sida crystallina, as well as occurrence of Pleuroxus trigonellus and Acroperus elongatus (SCZ IIIa) suggest a rising wa- ter temperature and climate warming. There was also an increase in fertility of the lake as evidenced by presence of Leydigia acanthocercoides species (Frey, 1986) and Alonella exigua, which is the indicator of $\beta$-mesotrophy in a lake (Adamska and Mikulski, 1968 ). The subsequent zone (SCZ IIIa) brought further improvements of living conditions and increase of a trophic level in the lake. In this phase there was the highest frequency of individuals of Cladocera. Probably, there could have been a decrease of a water level, as evidenced by increase in a frequency of bottom-dwelling species ( $A$. elongatus, $P$. trigonellus) and a layer of peat preserved in the sediments. The section contain Typha latifolia and Nympha alba (St-4 L PAZ) that present shallow coastal habitats convenient for these plants, while abundance of algae Pediastrum duplex, Pediastrum boryanum and Botryococcus is characteristic of eutrophic reservoirs (Daniluk, 2005). All this indicates the lake tendency to overgrow and shallowness. 
The next phase (SCZ IIIb, L PAZ St-5) brought a deterioration of living conditions in the lake. Both a frequency of individuals and a number of Cladocera species decreased. No species of Cladocera demanding a higher water temperature were found; but this fact does not give direct information whether the deterioration was caused by further lowering of water level (which could be also indicated by peat layer deposition) or perhaps was a result of a middle-interglacial cooling (Cheddadi et al., 1998). In this zone (St-5) there was virtually no aquatic plant pollen in the sediments (Kupryjanowicz, 2008). After deterioration, a renewed improvement of living conditions in the reservoir occurred (SCZ IIIc). A water temperature was high enough to be suitable for development of Cladocera species of higher thermal requirements: Camptocercus rectirostris, Pleuroxus laevis Pleuroxus trigonellus, Grabtoleberis testudinaria (Poulsen, 1944). Moreover, presence of $G$. testudinaria indicates a higher content of insoluble organic matter in the water. This species is also frequently found in peatlands (Duigan, 1992). A trophic status reached a eutrophic level, as evidenced by composition of the Cladocera species. The lake enabled development of the largest group of species, as evidenced by highest levels of biodiversity of Cladocera. Gradually, the conditions changed. Further species withdrew from the lake. The end of the middle Eemian was associated with a total lack of remains of Cladocera in the sediments. At the depth of $5 \mathrm{~m}$, remains of Cladocera were only sporadically identified. The second half of the palynological level E5 was associated with a strong decrease in the water level in the reservoirs of the northern Podlasie (Kupryjanowicz, 2008). It was a possible reason for temporary disappearance of the lake and its transformation into wetland.

\section{Late Eemian (SCZ IV; L PAZ St-6, St-7)}

Preserved remains were species resistant to environmental stress, such as Acroperus harpae, Alona affinis, small Alona and Chydorus sphaericus, which was the last to withdraw. Periodic presence of Cladocera and a break in its succession may indicate a temporary, short-term increase of a water level, which enabled existence of most resistant species. Remains of Cladocera occurred to the depth of $4.15 \mathrm{~m}$ in peat and peaty silts as well as organic silts. Above this depth, there were no Cladocera remains noted, which may indicate the termination of the lake. A disappearance of the lake was probably associated with its overgrowing with plants and filling with organic sediments, as well as with a supply of material derived from the hills surrounding the lake.

The development reconstruction presented above refers to the part of Starowlany from which the core was selected for the analysis. Unfortunately, there is no information whether it was the deepest part of the lake or a shallow bay which had undergone terrestrialization. The highest water level probably prevailed in the early Eemian. The increased temperature in the middle Eemian and local conditions of the position and supply led to the gradual shallowing of the lake and its transformation into a wetland with temporary increases of the water level.

\section{Starowlany paleolake development as compared with the Eemian and Holocene paleolakes in Poland}

The development of Starowlany reconstructed based on the Cladocera succession, bears resemblance to evolution of other Polish Eemian lakes. The end of the Warta Glaciation and the early Eemian were connected with formation and gradual deepening of lakes; their waters were cool and with low trophic levels (Niska, 2005). In the Lake Starowlany, just as in Sławoszewek in the Konin region (Pawlowski, 2011), Imbramowice in the Sudeten Foothills (MirosławGrabowska and Gąsiorowski, 2010), Lake Kubłowo (Niska and Roman, 2014), as well as at Besiekierz, (Mirosław-Grabowska and Niska, 2005), Studzieniec and the closely located Lake Solniki (Niska, 2008, ) the pioneer species dominated, inhabiting littoral zones, associated with aquatic vegetation and characterized by high tolerance to low temperatures. Gradually, towards the end of the early Eemian, the species with higher thermal and trophic levels requirements appeared. Improved conditions first occurred in central Poland in lakes Kubłowo, Studzieniec (Mirosław-Grabowska and Niska, 2007), Kuców IIc and Besiekierz. In the lakes located in the south (Imbramowice) and in north (Rzecino: Niska and Mirosław-Grabowska, 2014), as well as in eastern Poland (Starowlany and Solniki), improved climate conditions did not occur until the middle Eemian. With climate change, water level changed as well. The initially cool and humid climate of the early Eemian, constant supply of meltwaters and high groundwater level, provided a high level of water in the reservoirs (Kupryjanowicz, 2008). Gradual warming until a climax in the optimum (middle Eemian) (Zagwijn, 1996), a lack of meltwater supply and lowering groundwater level caused significant decrease of water levels in the Eemian lakes.

Initially, there was a significant improvement in edaphic conditions, a diversity of species increased and the appearing species were more demanding. In some reservoirs, however, these changes, beneficial at first, proved to be critical.

In most of the analyzed Eemian lakes (Kuców IIc, Studzieniec, Solniki, Sławoszewek) there was a drop in water level of which can be noted in changing composition of the remains of Cladocera species and peat layer deposits in lake sediments. Lowering of water level, however, was temporary only and was probably influenced by reservoir depths (Niska, 2008; Pawłowski, 2011). In lakes Starowlany, Besiekierz and Imbramowice the water level dropped so significantly that these lakes terrestrialized permanently.

A development of the Lake Starowlany in the Eemian is also related to the first lake development model in the Late Glacial and Holocene, presented by Szeroczyńska and Gąsiorowski (2002). In lakes Woryty and Niechorze, a similar Cladocera succession was observed, which terminated with a rather sudden transformation of lakes into peatlands and in a significant reduction of Cladocera succession to a few species occurring sporadically during climate moistening exclusively. A reason for a drop of water level in the Lake Starowlany during the middle Eemian was a climate change, including increased mean air temperature in cold and warm seasons, decreased annual rainfall to about $200-300 \mathrm{~mm}$ 
(Cheddadi et al., 1998) and increased evaporation (Kupryjanowicz, 2008). The terrestrialization was directly caused by hydrological, geological and morphometric properties of lake basins, with particular regard to size and depth of a lake and a watershed.

\section{CONCLUSIONS}

1. Lake Starowlany existed from the early until the middle Eemian Interglacial. In the late Eemian, terrestrialization of the lake occurred and water level rose periodically only, enabling existence of a few Cladocera species.

2. The Cladocera species preserved in the Starowlany section are similar to the species occurring in other Eemian lakes, as well as to the species common in Poland at present.

3. The species composition was dominated by taxa inhabiting a littoral zone, which suggests that most of the time of a single zone was a shallow one.

4. In the Lake Starowlany four development zones were distinguished, which reflected climate, trophic and water levels changes in the lake.

5. The highest water level occurred in zones SCZ I and II, while the most favorable conditions for zooplankton development and the highest trophic level occurred in SCZ III (middle Eemian).

6. A temporary deterioration of environmental conditions in the lake clearly marked itself in the middle Eemian (SCZ IIIb). It was probably associated with a local drop of water levels.

7. The reasons for disappearance of the Lake Starowlany were a climate change as well as morphometric and geological characteristics of a lake basin and a watershed.

8. The evolution zones of the Lake Starowlany are related to evolution of other Eemian and Holocene lakes in Poland and reflect local and global climate changes that took place in interglacial periods.

9. A reconstruction of the Lake Starowlany development zones distinguished on the basis of Cladocera population corresponds to results of palynological analysis of this section.

\section{Acknowledgements}

We would like to express our thanks to Dr. hab Mirosława Kupryjanowicz for providing the sediment samples and the very interesting cooperation. The research project was supported by the Foundation for Polish Science, Bridge Program 2012 in the project "Reconstruction of the development of lake environment in the Eemian Interglacial based on subfossil Cladocera (Crustacea) analysis".

\section{REFERENCES}

Adamska, A. Mikulski, J. S., 1968. Cladocera remains in the superficial sediments of lakes as typologic indicator. Zeszyty Naukowe UMK 25, Prace Stacji Limnologicznej w Iławie 5, $41-48$.

Boratyn, J., 2003. Szczegółowa Mapa Geologiczna Polski w skali 1:50 000 arkusz Sokółka (264). CAG PIG, Warszawa.

Boratyn, J., 2006. Objaśnienia do arkusza Sokółka Szczegółowej Mapy Geologicznej Polski w skali 1: 1:50 000. CAG PIG, Warszawa.
Cheddadi, R., Mamakowa, K., Guiot, J., de Beaulieu, J.-L., Reille, M., Andrieu, V., Granoszewski, W., Peyron, O., 1998. Was the climate of the Eemian stable? A quantitative climate reconstruction from seven European pollen records, Palaeogeography, Palaeoclimatology, Palaeoecology 143, 73-85.

Daniluk, E., 2005. Roślinność i klimat rejonu Sokółki czasie interglacjału eemskiego, praca magisterska, archiwum Uniwersytetu Białostockiego.

Duigan, C. A., 1992. The ecology and distribution of the littoral freshwater Chydoridae (Brachiopoda, Anomopoda) of Ireland, with taxonomic comments on some species. Hydrobiologia $241,1-70$.

Flössner, D., 1964. Zur Cladocerenfauna des Stechlinsgebietes, Il. Ökologishe Untersuchungen über die litoralen Arten. Limnologia, $131 \mathrm{pp}$.

Flössner, D., 1972. Branchipoda, Branchiura, Trierwelt Deutschl., $60,1-501$.

Flössner, D., 2000. Die Haplopoda und Cladocera (ohne Bosminidae) Mitteleuropas. Backhuys Publisher, Leiden, The Netherlands, $1-425$.

Frey, D.G., 1958. The late-glacial cladoceran fauna of small lake. Archives of Hydrobiology 54, 125-135.

Frey, D.G., 1962. Cladocera from the Eemian Interglacjal of Denmark. Journal of Palaeontology 36, 1133-1154.

Frey, D.G., 1986. Cladocera analysis In: Berglund B.E. (Ed.), Handbook of Holocene Palaeoecology and Palaeohydrology. John Wiley \& Sons, New York, 667-692.

Goulden, C.E., 1964. The history of the cladoceran fauna of Esthwaite Water (England) and its limnological significance. Archives of Hydrobiology 60, 1-53.

Hann, B.J., Karrow, P.F., 1984. Pleistocene paleoecology of the Don and Scarborough Formations, Toronto, Canada, based on Cladocera microfossils at the Don Valley Brickyard. Boreas 13, 377-391.

Hann, B.J., Karrow P. F., 1993. Comparative analysis of cladoceran microfossils in the Don and Scarborough Formations, Toronto, Canada, Journal of Paleolimnology 9, 223-241.

Hearty, P.J., Hollin, J.T., Neumann, A.C., O’Leary, M.J., McCulloch, M., 2007. Global sea-level uctuations during the Last Interglaciation (MIS 5e). Quaternary Science Reviews 26, 2090-2112.

Hofmann, W., 1986. Developmental history of the Grosser Plöner See and the Schöhsee (north Germany): cladoceran analysis, with special reference to eutrophication. Archives of Hydrobiology Supplement 74, 259-287.

Hofmann, W., 1987. Cladocera in space and time: Analysis of lake sediments. Hydrobiologia 145, 315-321.

Hofmann, W., 2000. Response of the chydorid faunas to rapid climatic changes in four alpine lakes at different altitudes. Palaeogeography, Palaeoclimatology, Palaeoecology 159, 281292.

Kadota, S., 1975. A quantative study of the microfossils in a 200-meter-long core sample from lake Biwa, Paleolimnology of lake Biwa and the Japanese Pleistocene, 85(3), p. 354-367.

Kajak, Z., 2001. Hydrobiologia - Limnologia. Ekosystemy wód śródlądowych, Wyd. PWN, Warszawa.

Korhola, A., 1990. Palaeolimnology and hydroseral development of the Kotasuo Bog, Southern Finland, with special reference to the Cladocera. Ann. Acad. Sci. Fenn., 55, 5-40.

Korhola, A., Rautio M., 2001. Cladocera and other branchiopod crustaceans. In: Smol J.P., Birks H.J.B., Last W.M. (Eds), Tracking Environmental Change Using Lake Sediments, Zoological Indicators 4, 5-41. Kluwer Academic Publishers, Dordrecht.

Krzywicki, T., 2006. Przegląd problemów badawczych górnego plejstocenu i rozwój badań nad zasięgami lądolodów skandy- 
nawskich w północnej części Niziny Podlaskiej. Rocznik Augustowsko-Suwalski 6, 55-64.

Kupryjanowicz, M., 2008. Vegetation and climate of the Eemian and Early Vistulian lakeland in northern Podlasie. Acta Palaeobotanica 48 (1), 3-130.

Mamakowa, K., 1989. Late Middle Polish Glaciation, Eemian and Early Vistulian vegetation at Imbramowice near Wrocław and the pollen stratigraphy of this part of the Pleistocene in Poland. Acta Palaeobotanica 29 (1), 11-176.

Mirosław-Grabowska, J., Gąsiorowski, M. 2010. Changes of water level in the Eemian palaeolake at Imbramowice (SW Poland) based on isotopic and cladoceran data. Quaternary Research 73(1), 143-150.

Mirosław-Grabowska, J., Niska M., 2005. Isotopic and Cladocera records of climate changes of Early Eemian at Besiekierz (central Poland), Geological Quarterly 49(1), 67-74.

Mirosław-Grabowska, J., Niska M., 2007. Reconstruction of environmental conditions of Eemian palaeolake at Studzieniec (Central Poland) on the basis of stable isotope and Cladocera analyses. Quaternary International 162-163, 195-204.

Mueller, W.P., 1964. The distribution of cladoceran remains in surficial sediments from three northern Indiana lakes. Invest. Indiana Lakes Streams 6, 1-63.

Nalepka, D., Walanus, A., 2003. Data processing in pollen analysis, Acta Palaeobotanica 43 (1), 125-134.

Niska, M., 2005. Interpretacja zmian środowiska jeziornego w interglacjale eemskim na podstawie analizy subfosylnych Cladocera. Ph.D. Thesis, Institute of Geological Sciences Polish Academy of Sciences, Warsaw, unpublished.

Niska, M., 2008. Interpretacja zmian środowiska jeziornego w interglacjale eemskim na podstawie analizy kopalnych Cladocera. Akademia Pomorska w Słupsku 127.

Niska, M., Mirosław-Grabowska, J., 2014. Eemian environmental changes recorded in lake deposits from Rzecino (NW Poland): Cladocera, isotopic and selected geochemical data. Journal of Paleolimnology. DOI 10.1007/s10933-014-9810-6.

Niska, M., Roman, M., 2014. Development of Kubłowo Palaeolake in Central Poland During Eemian Based on Subfossil Cladocera Analysis - preliminary results. Studia Quaternaria 31 (1), $31-37$.
Pawłowski, D., 2011. Evolution of an Eemian lake based on Cladocera analysis (Konin area, Central Poland). Acta Geologica Polonica 61, 441-450.

Poulsen, E., 1944. Entomostraca from a late-glacial lacustrine deposit at Nćstved, Denmark. Meddelelser fra Dansk Geologisk Forening 10, 405-416.

Rybak, J.J., Błędzki, L.A., 2010. Słodkowodne skorupiaki planktonowe, Wyd. Uniwersytetu Warszawskiego, Warszawa.

Szeroczyńska, K., 1985. Cladocera jako wskaźnik ekologiczny w późnoczwartorzędowych osadach jeziornych Polski północnej. Acta Paleontologica Polonica 30 (1-2). PWN, Warszawa.

Szeroczyńska, K., 1998a. Palaeolimnological investigations in Poland based on Cladocera (Crustacea). Palaeogeography, Palaeoclimatology, Palaeoecology 140, 335-345.

Szeroczyńska, K., 1998b. Wioślarki (Cladocera, Crustacea) jako źródło informacji w badaniach osadów jeziornych. Studia Geologica Polonica 112, 9-28.

Szeroczyńska, K., Gąsiorowski, M., 2002. Paleohydrological aspect of transformation of lakes into peat bogs during Middle Holocene on the basis of Cladocera analysis in the northern Poland. Studia Quaternaria 19, 55-60.

Szeroczyńska, K., Sarmaja-Korjonen, K., 2007. Atlas of Subfossil Cladocera from Central and Northern Europe. Friends of the Lower Vistula Society.

Tobolski, K., 1991. Biostratygrafia i paleoekologia interglacjału eemskiego i zlodowacenia Wisły rejonu konińskiego zestawienie tabelaryczne. In: Przemiany środowiska geograficznego obszaru Konin-Turek, UAM, Poznań, 45-88.

Tsukada, M., 1972. The history of lake Nojiri, Japan, Trans. Conn. Acad. Art. Sci., 44, s. 339-365.

Whiteside, M.C., 1970, Danish Chydorid Cladocera: modern ecology and core studied, Ecol. Monogr., 40(1), 79-118.

Whiteside, M.C, Swindoll, M.R., 1988. Guidelines and limitations to cladoceran paleoecological interpretations. Palaeography, Palaeoeclimatology, Palaeoecology 62, 405-412.

Zagwijn, W.H., 1996. An analysis of Eemian climate in western and central Europe. Quaternary Science Reviews 15, 451-469.

Zhang, Y., Cui, B., Lan, Y., Han, Z., Wang, T., Guo, A., 2012. Four terrestrialization characteristics of Baiyangdian Lake, China. 13 (1), 645-654. 